\section{Poor coordination 'wastes US research into global change'}

Mark Schrope, Washington

The infrastructure for coordinating US research into global change must be redesigned if politicians are to make properly informed decisions on big issues such as greenhouse-gas emission policies. This is the conclusion of a report from the National Research Council (NRC) which aims to influence the new Bush administration.

The report - The Science of Regional and Global Change: Putting Knowledge to Work - says poor coordination within and between agencies such as the space agency NASA and the National Oceanic and Atmospheric Administration (NOAA) has stopped politicians and researchers making full use of results.

For example, NASA's ocean remotesensing data must be calibrated and validated using measurements taken at the ocean surface which might best be carried out by NOAA. But although such work is critical for integrating the NASA data into models of global change, NOAA might see this as a low priority.

Moreover, the report says that critical challenges - such as accurate predictions on a global scale - call for improved computing capabilities and global monitoring systems which are beyond the capacity of individual agencies.

Charles Kennel, chairman of the NRC's Committee on Global Change Research, which produced the report, says accurate predictions of changes on a regional scale are also crucial.

"People can't answer the most important question in environmental science - what's going to happen to me?" he says. "The present system is not really capable of doing that."

The report proposes that globalchange research should be coordinated through a new, centralized government body. This would filter results to policymakers and fund critical projects.

The US Global Change Research Program, set up in 1990 to coordinate the efforts of government and other organizations, could be upgraded to take care of these new tasks, says the report. Or a new body could be created.

"I very much agree that some highlevel entity is needed, because we now have an amalgam of separate agency programmes where the goal of each agency is very different," says Marvin Geller, president of the atmospheric sciences section of the American Geophysical Union.

\title{
Bank raids malaria centre in dispute over landlord's debt
}

Xavier Bosch

Research at the Immunology Institute of Bogotá (IIB) in Colombia - headed by controversial biochemist Manuel Patarroyo - has been paralysed by debt collectors.

In a move that has precipitated angry demonstrations, a Spanish bank impounded the institute's equipment because it is owed $\$ 2.5$ million by the hospital in which the institute is located.

Three weeks ago, the BBVA Banco Ganadero bank, which has extensive interests in Latin America, took control of the IIB's supercomputers, DNA sequencers and nuclear magnetic resonance equipment, which is used to determine the threedimensional structures of proteins.

The bank accepts that the IIB is only associated with, and not owned by, the Foundation Hospital San Juan de Dios, which owes the money. But the bank's president José Maria Ayala, a Spaniard, says that, after several attempts to redeem debts from the hospital by confiscating property, there was "nothing else left of value to impound". He says he had recommended that Patarroyo leave the hospital and move elsewhere.

But Patarroyo says the bank had no right to involve the IIB, which, he argues, is almost entirely independent of the foundation that runs the hospital, being directly funded by the Colombian presidency. Only the building itself and half the salaries of 20 out of the 168 researchers are provided by the foundation, he says.

The foundation, which manages four health and research centres in Bogotá on an annual budget of $\$ 60$ million, was driven into severe debt by Colombia's general financial difficulties combined with the privatization of the foundation.

The bank's action has generated intense local ill-feeling — Patarroyo says he has had to persuade an angry demonstration of

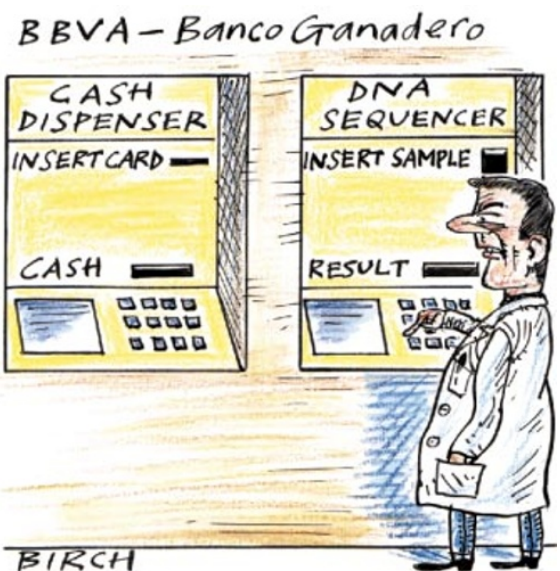

ผ ๑ 2001 Macmillan Magazines Ltd

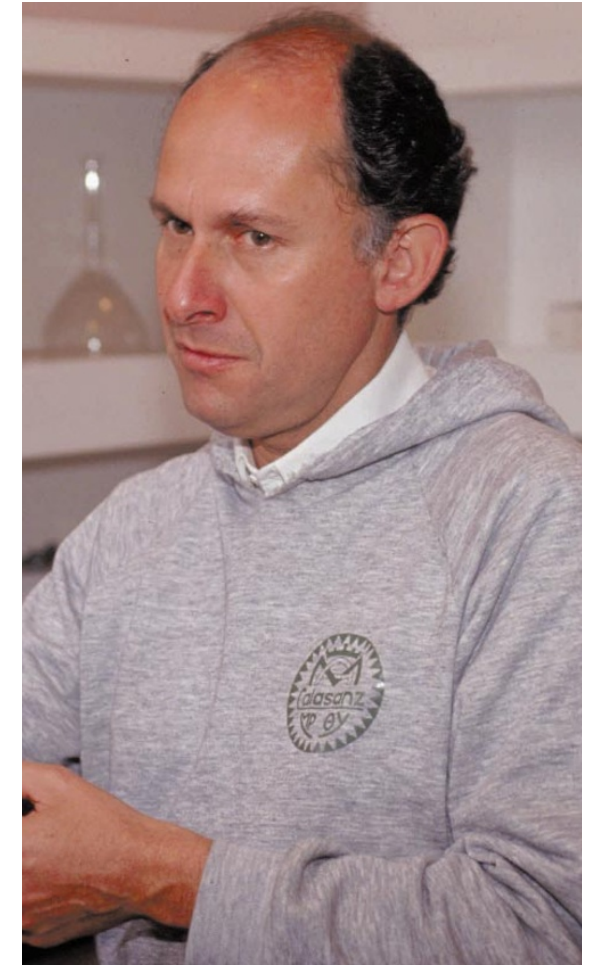

Patarroyo: work on malaria vaccine has been paralysed by removal of institute equipment.

students and young researchers not to storm the bank. And Colombian newspapers have published letters calling for investors to withdraw their capital from the bank.

"There is even a bit of anti-Spanish feeling among people now," says Patarroyo, who has strong research links with Spain.

Patarroyo became famous in Colombia when he created a synthetic malaria vaccine containing peptides derived from three asexual blood-stage proteins of the protozoan parasite Plasmodium falciparum.

But he was frequently attacked by the scientific community during the late 1980s and early 1990s over methodological issues, including the launch of what was considered by many to be a badly designed clinical trial involving over 20,000 Colombians. The vaccine was eventually shown to have low but significant efficacy, which his research team has since been trying to improve by incorporating more peptides. Patarroyo says he hopes to have an improved vaccine ready for clinical testing within two years.

The IIB received about $\$ 3$ million from the Colombian presidency last year, under an agreement linking funding to research output. Ayala says he hopes to find a solution that would allow him to have the impounded goods returned, perhaps through the intervention of the Colombian presidency. 